\title{
Field Observations of Changes in SST, Chlorophyll and POC Flux in the Southern East China Sea Before and After the Passage of Typhoon Jangmi
}

\author{
Yung-Yen Shih ${ }^{1}$, Jin-Sheng Hsieh ${ }^{2}$, Gwo-Ching Gong ${ }^{2,3}$, Chin-Chang Hung ${ }^{1,3, *}$, Wen-Chen Chou ${ }^{2}$, \\ Ming-An Lee ${ }^{4}$, Kuo-Shu Chen ${ }^{1}$, Meng-Hsien $\mathrm{Chen}^{1}$, and Chau-Ron $\mathrm{Wu}^{5}$ \\ ${ }^{1}$ Department of Oceanography, and Asia-Pacific Ocean Research Center, National Sun Yat-sen University, Kaohsiung, Taiwan \\ ${ }^{2}$ Institute of Marine Environmental Chemistry and Ecology, and Center of Excellence for Oceans, \\ National Taiwan Ocean University, Keelung, Taiwan \\ ${ }^{3}$ Taiwan Ocean Research Institute, National Applied Research Laboratories, Kaohsiung, Taiwan \\ ${ }^{4}$ Department of Environmental Biology and Fisheries Science, National Taiwan Ocean University, Keelung, Taiwan \\ ${ }^{5}$ Department of Earth Sciences, National Taiwan Normal University, Taipei, Taiwan
}

Received 10 January 2013, accepted 23 May 2013

\begin{abstract}
Severe tropical storms play an important role in triggering phytoplankton blooms, yet direct field observation of evidence of the effects of a typhoon is very rare. Sea surface temperature (SST), nitrate concentration, chlorophyll $a$ (chl $a$ ) concentration, and particulate organic carbon (POC) flux were measured before and shortly after Typhoon Jangmi which affected the southern East China Sea (SECS) on September $28 \sim 29,2008$. In situ SST (27.5 28.0 ${ }^{\circ}$ ) on September $19 \sim 21$, decreased to $\sim 24.0^{\circ} \mathrm{C}$ (October $3 \sim 6$ ) in the SECS $4 \sim 7$ days after the passage of Typhoon Jangmi. In situ nitrate and chl $a$ concentrations 7-days (on October 6) after the passage of Jangmi were $1.9 \mu \mathrm{M}$ and $1.61 \mathrm{mg} \mathrm{m}^{-3}$, respectively, much higher than those (nitrate: $0.3 \mu \mathrm{M}$ and chl $a: 0.73 \mathrm{mg} \mathrm{m}^{-3}$ ) concentrations before the typhoon (September 21 ). The enhanced chl $a$ concentration is thus caused by a nutrient supply via vertical mixing or upwelling in the euphotic zone. The POC flux 7-days after Jangmi's passage was $552 \pm 28 \mathrm{mg}-\mathrm{C} \mathrm{m}^{-2} \mathrm{~d}^{-1}$, a $\sim 2.5$-fold increases before the typhoon $\left(224 \pm 33 \mathrm{mg}_{-} \mathrm{C} \mathrm{m}^{-2} \mathrm{~d}^{-1}\right.$, on September 21$)$. Our results suggest that typhoons indeed can stimulate efficient POC export out of the euphotic zone, while it is still poorly understood with regard to the total effects of a typhoon on nutrient dynamics and detailed carbon sequestration due to sampling difficulty. Therefore, successional sea-going observations ought to be conducted in the affected area after the passage of typhoons.
\end{abstract}

Key words: Typhoon, Hurricane, Sea surface temperature, Chlorophyll, East China Sea, POC flux

Citation: Shih, Y. Y., J. S. Hsieh, G. C. Gong, C. C. Hung, W. C. Chou, M. A. Lee, K. S. Chen, M. H. Chen, and C. R. Wu, 2013: Field observations of changes in SST, chlorophyll and POC flux in the southern East China Sea before and after the passage of Typhoon Jangmi. Terr. Atmos. Ocean. Sci., 24, 899-910, doi: 10.3319/TAO.2013.05.23.01(Oc)

\section{INTRODUCTION}

Research has shown that tropical cyclones (e.g., typhoons in the Pacific and hurricanes in the Atlantic) or dust storm events have pronounced affects on nutrient supply, phytoplankton activities, primary production, pollutant discharge, rainfall, and carbon cycling (Chang et al. 1996, 2008; Babin et al. 2004; Hung et al. 2005, 2007, 2009, 2010a; Walker et al. 2006; Zheng and Tang 2007; Shang et al. 2008; Chou et al. 2009, 2011; Huang et al. 2011; Chen and Tang 2012; Jan et al. 2013). Previous studies of typhoon induced phytoplankton blooms are largely based on satellite

\footnotetext{
* Corresponding author

E-mail: cchung@mail.nsysu.edu.tw
}

remote sensing data. However, it can be difficult to obtain clear ocean color images during or shortly after the typhoon passages because of extensive cloud cover. Consequently, most typhoon-related investigations in remote oligotrophic oceanic regions and/or marginal seas are mainly based on satellite images and wind speeds of typhoons, while a few papers report in situ sea surface temperature (SST), nutrient, chlorophyll (chl $a$ ) data after typhoons (Shiah et al. 2000; Fritz et al. 2007; Chen et al. 2009; Hung et al. 2010a, 2013; Rao et al. 2010; Hung and Gong 2011; Chung et al. 2012). Most importantly, evidence of sinking particles carrying $\mathrm{POC}$ out of the euphotic zone, a potential strategy to sequester $\mathrm{CO}_{2}$ from the atmosphere, is still poorly understood. Hung et al. (2010a) reported POC fluxes and other 
parameters (satellite-derived chl $a$, SST, nutrients etc.) in the SECS after a typhoon, but they did not measure POC fluxes before a typhoon. As a consequence, it is difficult to elucidate the detailed ocean biogeochemical processes, especially for POC flux before the passage of a typhoon. To assess whether typhoons can have impact on carrying biogenic particles down to the euphotic zone, direct measurements of POC fluxes to the euphotic zone (or deep water) before and after typhoons are needed.

According to historical typhoon records (www.cwb. gov.tw), three to four typhoons pass the SECS each year. The SECS is not an oligotrophic region, yet there is no large river input into the region, and thus, the satellite ocean color data in the study area are likely representative of the sea conditions unaffected by terrestrial materials (Liu et al. 1995; Hung et al. 2000, 2012). Moreover, in the SECS, the sediment trap-collected material (e.g., biogenic POC) is less likely to be affected by bottom-sediment re-suspension due to the fact that the bottom (off northeast Taiwan) is mainly composed of rock and coral materials. Even though an upwelling phenomenon (mainly below $150 \mathrm{~m}$ ) off northeast Taiwan has been reported by Wu et al. (2008a), the cold dome in the surface water on the shelf-break in the study area of the SECS has only been intermittently observed in summer (Chern et al. 1990; Liu et al. 1992; Gong et al. 1995; Jan et al. 2011).

Typhoon Jangmi was strong (sustained winds $=53 \mathrm{~m} \mathrm{~s}^{-1}$ ) and passed through the SECS on September $28 \sim 29,2008$. Therefore, we had a unique opportunity to conduct sea-based observations in the affected area of the SECS $5 \sim 7$ days following the typhoon. We were only able to measure SST, surface nitrate concentration, chl $a$ concentration, and POC flux, but no vertical hydrographic data during this typhoon's passage could be obtained. Hence, the main objective of this study is thus to compare in situ measurements of SST, nitrate and chl $a$ concentrations, and POC fluxes in the SECS before $(9 / 19 \sim 9 / 21)$ and after $(10 / 3 \sim 10 / 6)$ the passage of Typhoon Jangmi.

\section{MATERIALS AND METHODS}

Sea-based experiments were conducted in the SECS $\left(25.5^{\circ} \mathrm{N}, 122.0^{\circ} \mathrm{E}\right.$, indicated as a blue asterisk in Fig. 1, water depth $\sim 130 \mathrm{~m}$, approximately $70 \mathrm{~km}$ northeast of Taiwan), on the research vessel Yang-Ming 66, with five separate cruises on 9/17 (mm/dd), 9/19, 9/21 (three September cruises defined as field observations before Typhoon Jangmi), 10/3 and 10/6 (two October cruises defined as field observations after Typhoon Jangmi) in 2008. Surface seawater samples were collected using a clean water bucket at trap deployment and recovery time. In situ SST was immediately measured by a calibrated mercury thermometer (accuracy $\sim 0.05^{\circ} \mathrm{C}$ at $25^{\circ} \mathrm{C}$ ) at trap deployment and recovery time. Subsamples for nutrient analysis were stored in liquid nitrogen on board ship and stored at $-20^{\circ} \mathrm{C}$ until analysis. Concentration of nitrate was analyzed with a self-designed flow injection analyzer (Gong et al. 1992). The chl $a$ samples were collected by filtering $500 \mathrm{ml}$ of seawater through a $\mathrm{GF} / \mathrm{F}$ filter and stored at $-20^{\circ} \mathrm{C}$ until analysis. Concentration of chl $a$ on the GF/F filter was determined according to standard procedures using a Turner Designs 10-AU-005 fluorometer by the non-acidification method (Gong et al. 2000). In addition, we also estimated chl $a$ values in the study area $\left(25.5^{\circ} \mathrm{N}, 122.0^{\circ} \mathrm{E}\right)$ using the Moderate Resolution Imaging Spectroradiometer (MODIS) (the average value from Aqua and Terra), but only obtained data on 9/26, $10 / 5$ and $10 / 8$ due to heavy cloud cover. Sinking particles were collected at $70 \mathrm{~m}$ (below the euphotic zone $\sim 40-60 \mathrm{~m}$, Hung and Gong 2011) using a drifting sediment trap array, which consisted of six cylindrical plastic core tubes (Hung et al. 2003, 2004; Hung and Gong 2007). The trap tubes, filled with filtered seawater $(<0.5 \mu \mathrm{m})$ in order to reduce the possible added material from swimmers (e.g., zooplankton), were deployed daily $\sim 5$ hours at a depth of $70 \mathrm{~m}$. Aliquots from sediment traps were filtered through quartz filters (Whatman QMA, pore size: $1 \mu \mathrm{m}$ ) as described in Hung et al. (2009). The swimmers, evident on the filters were carefully removed under a microscope using forceps. After fuming with $\mathrm{HCl}$, the $\mathrm{POC}$ concentrations on the filters were measured using an elemental analyzer (Elementa, Vario EL-III, Germany). Poisons were not used, as Hung et al. (2010a) compared POC flux collected by un-poisoned traps to those in poisoned traps in the northwest Pacific Ocean and found that the POC flux $\left(187 \pm 9 \mathrm{mg}_{-} \mathrm{C} \mathrm{m}^{-2} \mathrm{~d}^{-1}\right)$ in the poisoned traps seems to be not significantly higher than that $\left(167 \pm 3 \mathrm{mg}-\mathrm{C} \mathrm{m}^{-2} \mathrm{~d}^{-1}\right)$ in un-poisoned traps for a short-term trap deployment.

Wind speed data during the passage of Typhoon Jangmi were provided by the Central Weather Bureau of Taiwan. Satellite SST from $21 \sim 28^{\circ} \mathrm{N}$ and 118 to $125^{\circ} \mathrm{E}$ was estimated using Advanced Very High Resolution Radiometer infrared sensors (defined as ASST, Chang et al. 2008). Additionally, the cloud-penetrating SST (defined as CPSST) data from Tropical Rainfall Measuring Mission (Microwave Imager) were used to estimate SST between $25.38 \sim 25.62^{\circ} \mathrm{N}$ and $122.12 \sim 122.38^{\circ} \mathrm{E}$ (Wu et al. 2008a). Primary productivity (PP) was derived using a chl $a$-temperature algorithm based on a function of maximum carbon fixation within a water column (Gong et al. 2001). This algorithm is briefly described:

$\hat{P}^{B}(z)=P_{e u}^{B}\left\{1-\exp \left[-S_{e u} \bar{E}(z) / P_{e u}^{B}\right]\right\}$

where $\hat{P}^{B}(z)$ is a carbon fixation rate at the sampling depth, $P_{e u}^{B}$ represents the highest $\overline{P^{B}}$ reached when the daytime averaged downwelling irradiance $\bar{E}$ is strong, and $S_{e u}$ is a representative slope of $\overline{P^{B}}(\bar{E})$ curve for the euphotic layer. 

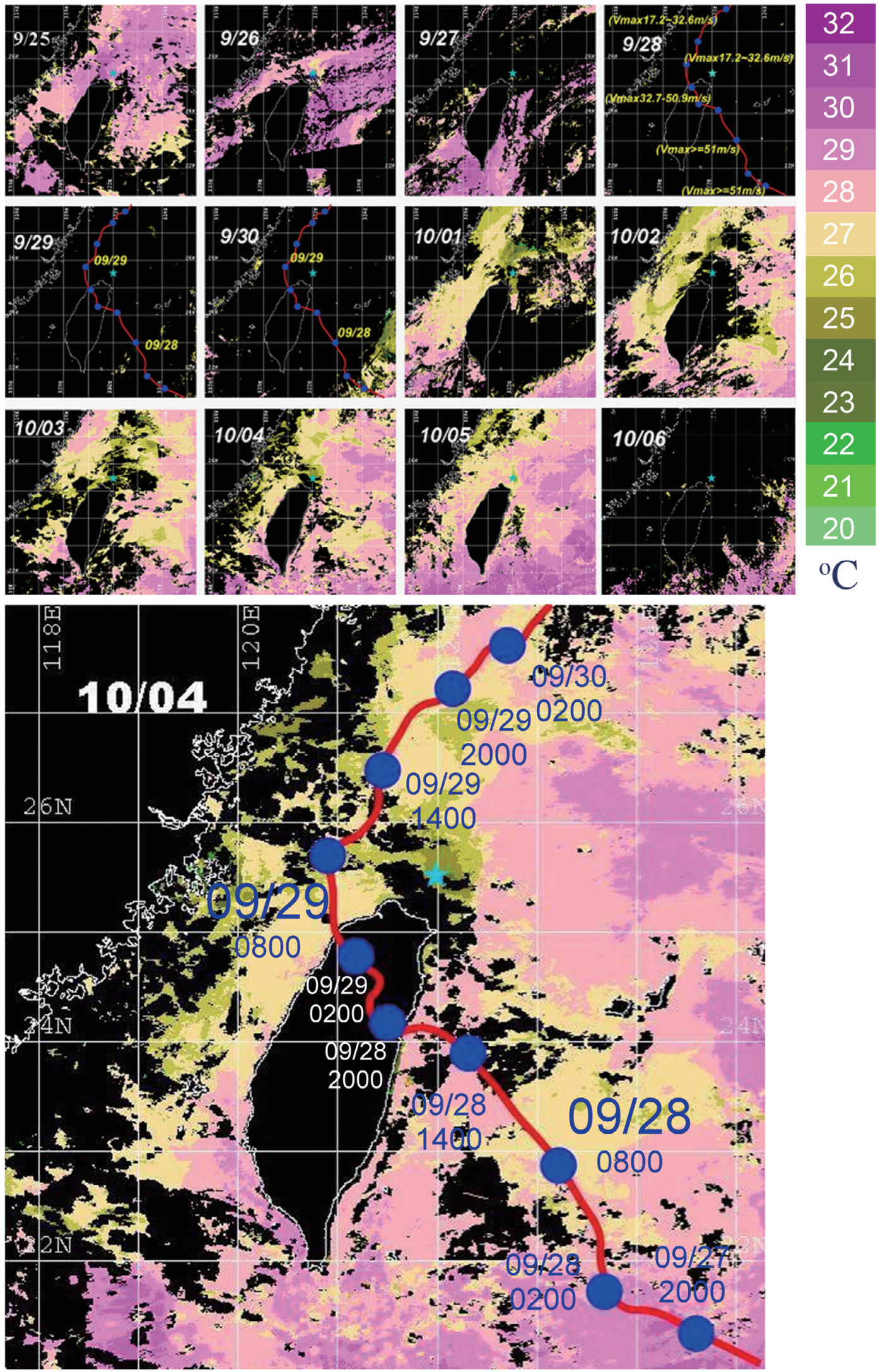

Fig. 1. Upper panel: Variation of AVHRR SST (ASST) satellite images in the southern East China Sea before (25 27 September) and after (28 September $\sim 6$ October) Typhoon Jangmi. Lower panel: ASST image on 4 October only. Star symbol in the upper panel represents in situ sampling location. The black area indicates heavy cloud cover or land. The red line indicates a moving track, and a blue circle represents the center of Jangmi every 6 hours. 
In this equation (Behrenfeld and Falkowski 1997), sea surface photosynthetically active radiation, the euphotic zone depth (depth of $1 \%$ surface light penetration), chlorophyll concentration and photoperiod, were modified according to Gong et al. (2001). The calculated euphotic zone integrated primary production (CIP) was then estimated by trapezoidal integration, thus,

$$
\mathrm{CIP}=\int_{0}^{z_{e}} \hat{P}^{B}(z)[\operatorname{chl} a](z) d z
$$

Consequently, the integrated primary production in the euphotic zone can accurately be estimated by this algorithm.

\section{RESULTS}

\subsection{SST and Nitrate Concentration Before and After the Passage of Typhoon Jangmi}

The Typhoon Jangmi was a powerful typhoon (maximum sustained winds near the center was $53 \mathrm{~m} \mathrm{~s}^{-1}$ with wind gusts $\geqq 63 \mathrm{~m} \mathrm{~s}^{-1}$, similar to a category 4 hurricane on the Saffir-Simpson hurricane wind scale); its radius of wind speed over $15 \mathrm{~m} \mathrm{~s}^{-1}$ and $26 \mathrm{~m} \mathrm{~s}^{-1}$ were $280 \mathrm{~km}$ and $100 \mathrm{~km}$, respectively. Jangmi traveled at $4.7 \sim 5.5 \mathrm{~m} \mathrm{~s}^{-1}$ on $26 \sim 27$ September and $3.3 \sim 3.8 \mathrm{~m} \mathrm{~s}^{-1}$ on $28 \sim 29$ September, 2008 (Fig. 1). The variation of SST in the study region from $9 / 25$ ( $\mathrm{mm} / \mathrm{dd}$ ) to $10 / 6$ and detailed SST image on 10/4 are shown in Fig. 1 where most images $(9 / 27 \sim 9 / 30)$ are just black (due to heavy cloud cover) and some images $(10 / 1 \sim 10 / 5)$ are visible. According to the SST variation in Fig. 1, SST images of the surface water of the SECS after the passage of Typhoon Jangmi showed a markedly cooler reading $\left(\sim 24^{\circ} \mathrm{C}\right.$ on $10 / 4)$ than before the typhoon passage $\left(\sim 27\right.$ to $29^{\circ} \mathrm{C}$ on 9/25). The measured SST at the trap deployment-recovery time in the SECS on 9/19 and 9/21 (e.g., a week before Typhoon Jangmi's passage) were 28.3 and $27.6^{\circ} \mathrm{C}$, and 28.0 and $27.5^{\circ} \mathrm{C}$, respectively. The measured SST at the trap deployment-recovery time in the SECS on $10 / 3$ and $10 / 6$ (e.g., a week after Typhoon Jangmi's passage) were 24.6 and $24.7^{\circ} \mathrm{C}$, and 23.7 and $24.2^{\circ} \mathrm{C}$, respectively. Basically, the measured SST in the study area showed notable differences pre-typhoon $\left(28.0 \pm 0.5^{\circ} \mathrm{C}\right.$ on $9 / 19$ and $27.5 \pm 0.4^{\circ} \mathrm{C}$ on 9/21) from post-Typhoon Jangmi's passage conditions $\left(24.6 \pm 0.1^{\circ} \mathrm{C}\right.$ on $10 / 3$ and $24.0 \pm 0.3^{\circ} \mathrm{C}$ on $\left.10 / 6\right)$. Thus, the observed cooling phenomenon in the SECS was primarily associated with the effect of Typhoon Jangmi (Fig. 2a).

The in situ average (one at trap deployment and the other at recovery time) nitrate concentrations in the study area on 9/17, 9/19 and 9/21 (e.g., a week before Typhoon Jangmi's passage) were $0.3 \pm 0.1,0.2 \pm 0.1$ and $0.3 \pm 0.1 \mu \mathrm{M}$ (Table 1), respectively. The in situ average (one at trap deployment and the other at recovery time) nitrate concentrations in the study area on 10/3 and 10/6 (e.g., a week after Typhoon Jangmi's passage) were $2.3 \pm 1.1$, and $1.9 \pm 0.5 \mu \mathrm{M}$
(Table 1), respectively. Variations of surface nitrate concentrations clearly show that in situ nitrate concentrations 4 and 7 days after the passage of Typhoon Jangmi increased over 5- to 6-fold over that recorded before the typhoon (Fig. 2a). Based on this fact, Typhoon Jangmi indeed brought cold nutrient-rich water up to the surface layer from subsurface and/or deep water because of strong winds and a slow transition speed (Babin et al. 2004; Zheng and Tang 2007).

\subsection{In situ Chl $a$ and POC Flux Before and After the Passage of Typhoon Jangmi}

The in situ average (one at trap deployment time and the other at trap recovery time) chl $a$ concentrations in the study area on 9/17, 9/19 and 9/21 (e.g., a week before Typhoon Jangmi's passage) were $0.47 \pm 0.02,0.85 \pm 0.11$ and $0.73 \pm 0.20 \mathrm{mg} \mathrm{m}^{-3}$ (Table 1), respectively. The in situ average (one at trap deployment time and the other at recovery time) chl $a$ concentrations in the study area on $10 / 3$ and 10/6 (e.g., a week after Typhoon Jangmi's passage) were $0.92 \pm 0.08$ and $1.61 \pm 0.16 \mathrm{mg} \mathrm{m}^{-3}$ (Table 1, Fig. 2b), respectively. In comparison, chl $a$ concentrations 7-day after the typhoon were higher than those $\left(0.47,0.85\right.$ and $0.73 \mathrm{mg} \mathrm{m}^{-3}$ on $9 / 17,9 / 19$ and 9/21, respectively) before Typhoon Jang$\mathrm{mi}$, and significantly higher than those $\left(0.23\right.$ and $\left.0.41 \mathrm{mg} \mathrm{m}^{-3}\right)$ measured during a period (June and August, 2007) when no typhoon occurred (Hung et al. 2010b). Variations of in situ chl $a$ concentrations indicate that surface phytoplankton biomass significantly increased $4 \sim 7$ days after Typhoon Jangmi. Due to heavy cloud shading (Fig. 1) over the study area $\left(25.50^{\circ} \mathrm{N}, 122.0^{\circ} \mathrm{E}\right)$, the derived average MODIS chl $a$ concentrations in similar region were only available on $9 / 26$ $\left(0.32 \mathrm{mg} \mathrm{m}^{-3}\right), 10 / 5\left(1.5 \mathrm{mg} \mathrm{m}^{-3}\right)$ and $10 / 8\left(0.39 \mathrm{mg} \mathrm{m}^{-3}\right)$, respectively (Lee et al., personal communication). The satellite derived results suggest that chl $a$ concentration (e.g., phytoplankton biomass) was low before Typhoon Jangmi and then increased to $1.5 \mathrm{mg} \mathrm{m}^{-3} 6$ days after the passage of Typhoon Jangmi.After the peak, derived-chl $a$ concentration decreased to $0.39 \mathrm{mg} \mathrm{m}^{-3} 9$ days (e.g., 10/8) after Typhoon Jangmi. The sea-based measured chl $a$ concentration $\left(1.61 \pm 0.16 \mathrm{mg} \mathrm{m}^{-3}\right)$ on 10/6 was in good agreement with the derived chl $a$ value $\left(1.5 \mathrm{mg} \mathrm{m}^{-3}\right)$ on $10 / 5$ by MODIS, although the day is slightly different. It seems that both the in situ observations and the satellite derived surface chl $a$ concentrations after typhoons have a similar trend.

Summer POC fluxes under no typhoon conditions were $160 \pm 20 \mathrm{mg}-\mathrm{C} \mathrm{m}^{-2} \mathrm{~d}^{-1}$ in the SECS in 2007 (Fig. 3) (Hung and Gong 2011). Hung et al. (2010b) reported that the POC flux $\left(265 \pm 14 \mathrm{mg}_{-} \mathrm{C} \mathrm{m}^{-2} \mathrm{~d}^{-1}\right)$ in the SECS in early August 2008, 5 days after the passage of a medium Typhoon Fungwong (sustained winds $=43 \mathrm{~m} \mathrm{~s}^{-1}$ ) was $\sim 1.7$-fold that $\left(160 \pm 20 \mathrm{mg}_{-} \mathrm{C} \mathrm{m}^{-2} \mathrm{~d}^{-1}\right)$ recorded during a period when no typhoons occurred. The POC fluxes in the same study area 9 and 7 days before Typhoon Jangmi were approximately 
(a)

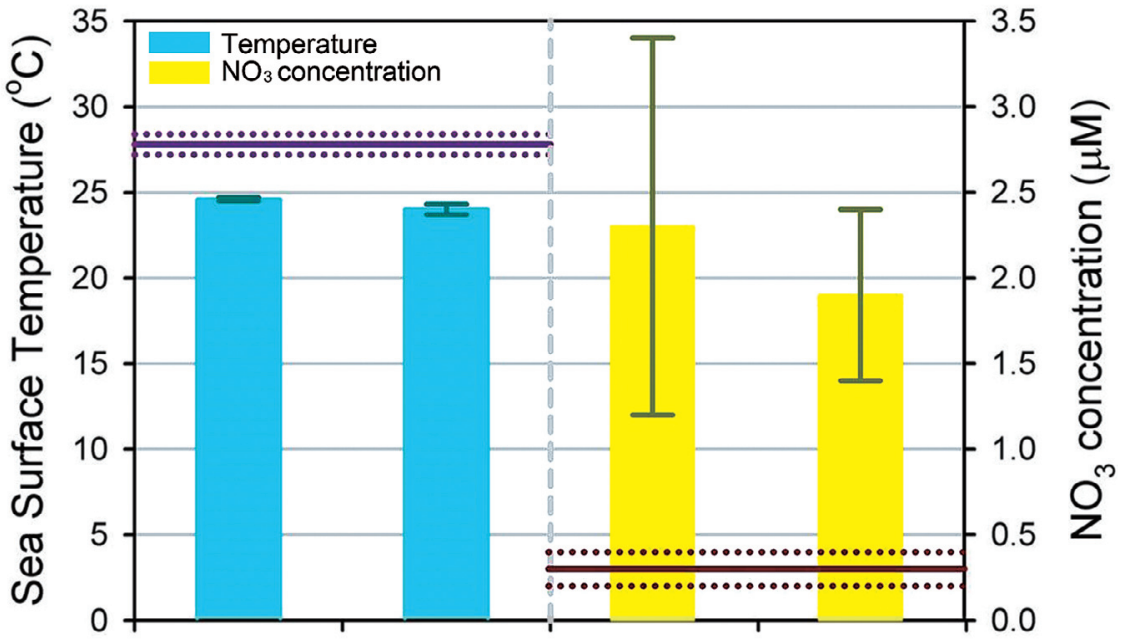

(b)

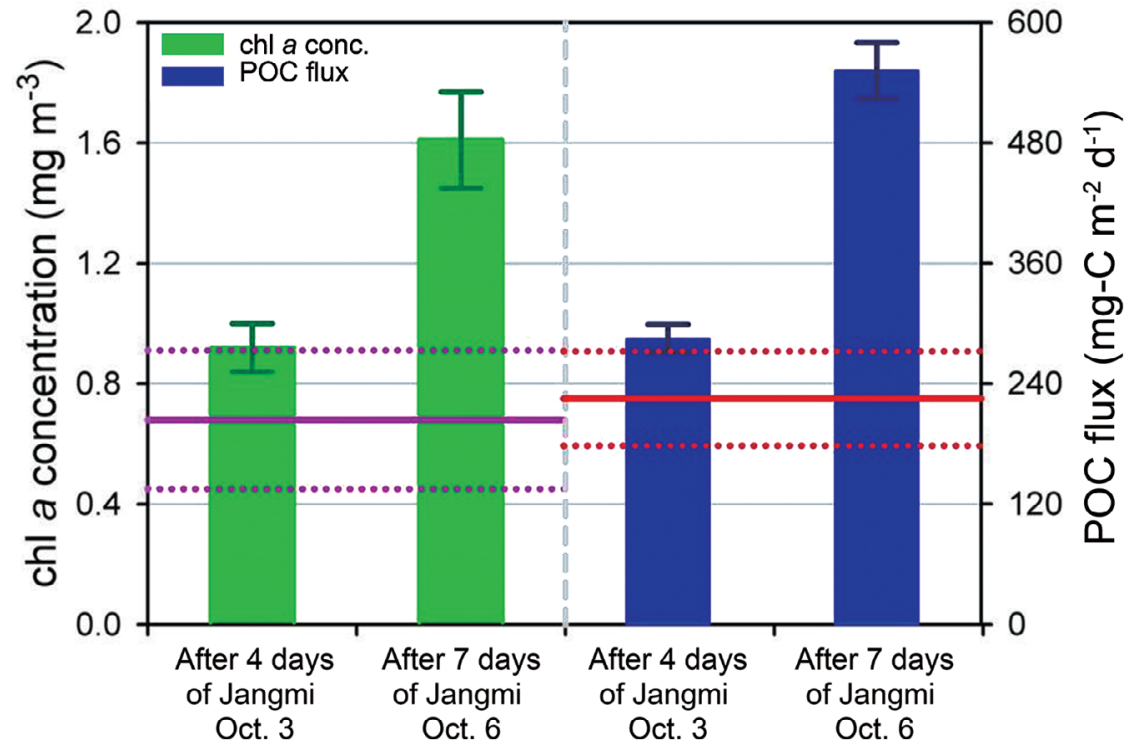

Fig. 2. (a) Sea surface temperature $\left({ }^{\circ} \mathrm{C}\right)$ and $\mathrm{NO}_{3}$ concentration $(\mu \mathrm{M})$ in the study region during Typhoon Jangmi on $9 / 28$ and $9 / 29$ in 2008 . The solid and dashed lines represent the average values and error bars before the typhoon $\left(9 / 17,9 / 19\right.$ and 9/21, 2008). (b) Chl $a$ concentration (mg m ${ }^{-3}$ ) and POC flux (mg-C m ${ }^{-2} \mathrm{~d}^{-1}$ ) in the study region during Typhoon Jangmi on 9/28 and 9/29 in 2008. The solid and dashed lines represent the average values and error bars before the typhoon $(9 / 17,9 / 19$ and 9/21, 2008).

Table 1. Data of in situ sea surface temperature (T), surface $\mathrm{NO}_{3}$, and chl $a$ concentrations, POC flux, integrated primary production (I-PP) and e-ratio (POC flux/I-PP) in the southern East China Sea before and after Typhoon Jangmi (passed over SECS on 9/28 29) in 2008.

\begin{tabular}{|c|c|c|c|c|c|c|c|}
\hline Date $(\mathbf{m m} / \mathbf{d d})$ & $\begin{array}{l}\text { Typhoon } \\
\text { condition }\end{array}$ & $\mathbf{T}\left({ }^{\circ} \mathbf{C}\right)$ & $\mathrm{NO}_{3}(\mu \mathrm{M})$ & $\operatorname{chl} a\left(\mathrm{mg} \mathrm{m}^{-3}\right)$ & $\begin{array}{c}\text { POC flux } \\
\left(\mathbf{m g}-\mathbf{C} \mathbf{~ m}^{-2} \mathbf{d}^{-1}\right)\end{array}$ & $\begin{array}{c}\text { I-PP } \\
\left(\mathbf{m g}-\mathbf{C} \mathbf{~ m}^{-2} \mathbf{d}^{-1}\right)\end{array}$ & e-ratio \\
\hline $9 / 17$ & before & N/A & $0.3 \pm 0.1$ & $0.47 \pm 0.02$ & N/A & N/A & N/A \\
\hline $9 / 19$ & before & $28.0 \pm 0.5$ & $0.2 \pm 0.1$ & $0.85 \pm 0.11$ & $225 \pm 34$ & 1384 & 0.16 \\
\hline $9 / 21$ & before & $27.5 \pm 0.4$ & $0.3 \pm 0.1$ & $0.73 \pm 0.20$ & $224 \pm 33$ & 1711 & 0.13 \\
\hline $10 / 3$ & after & $24.6 \pm 0.1$ & $2.3 \pm 1.1$ & $0.92 \pm 0.08$ & $285 \pm 14$ & 1367 & 0.21 \\
\hline $10 / 6$ & after & $24.0 \pm 0.3$ & $1.9 \pm 0.5$ & $1.61 \pm 0.16$ & $552 \pm 28$ & 1945 & 0.28 \\
\hline
\end{tabular}

Note: All data (except for I-PP, estimated via Gong et al. 2001) were measured based on sea-based experiments. e-ratio $=(P O C$ flux $/ I-P P)$. All hydrographic data were averaged values from deployment and recovery time. 


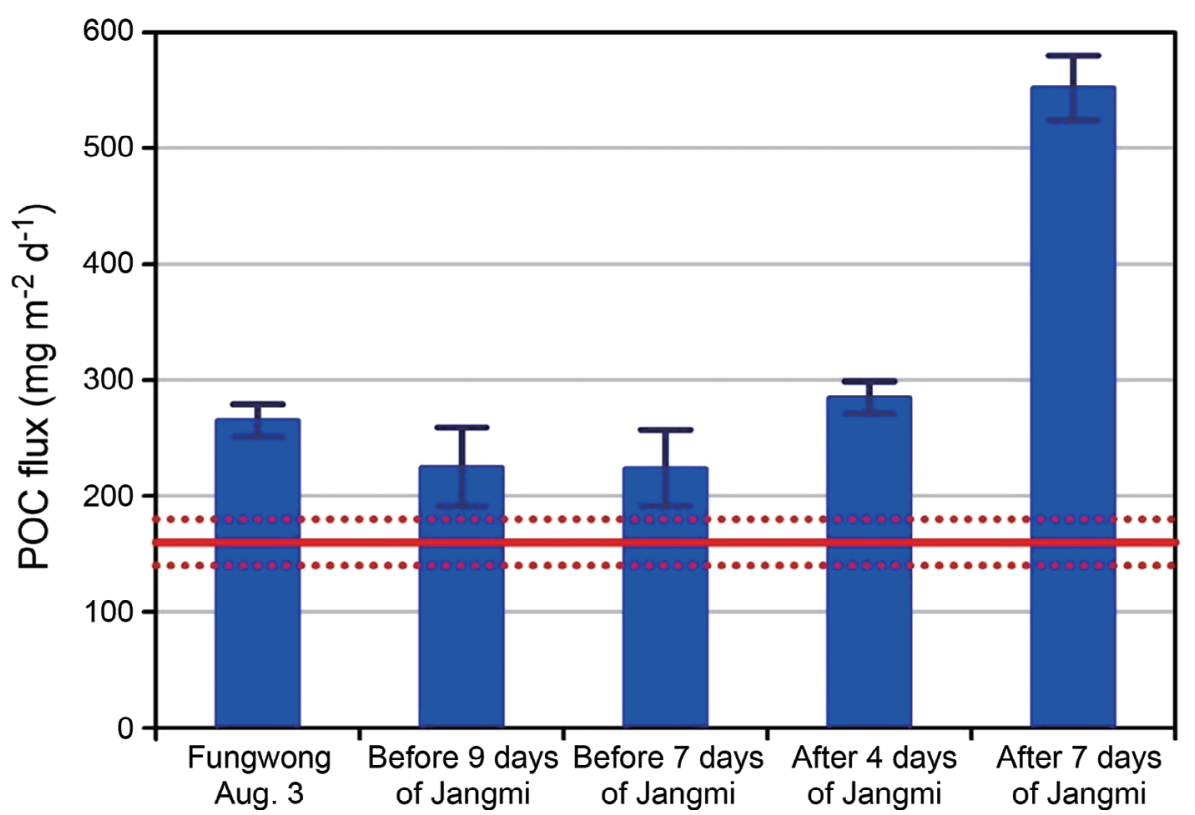

Fig. 3. POC fluxes (mg-C m $\left.\mathrm{m}^{-2} \mathrm{~d}^{-1}\right)$ in the study region during typhoon events in 2008 on 8/3 (Typhoon Fungwong), before 7 and 9 days, and after 4 and 7 days of Jangmi. The solid and dashed red lines represent the estimated POC export flux $\left(160 \pm 20 \mathrm{mg}_{-} \mathrm{C} \mathrm{m}^{-2} \mathrm{~d}^{-1}\right)$ and error bars in the same study area of the SECS in summer 2007 under non-typhoon conditions (Hung et al. 2010b).

$225 \pm 34$ and $224 \pm 33 \mathrm{mg}-\mathrm{C} \mathrm{m}^{-2} \mathrm{~d}^{-1}$, respectively. POC fluxes at $70 \mathrm{~m}$ in the SECS were approximately $285 \pm 14$ (10/3, month/date) and $552 \pm 28 \mathrm{mg}-\mathrm{C} \mathrm{m}^{-2} \mathrm{~d}^{-1}(10 / 6), 4$ and 7 days after the passage of Typhoon Jangmi (Table 1), respectively. The results showed that POC fluxes slowly increased from $225 \pm 34 \mathrm{mg}-\mathrm{C} \mathrm{m}^{-2} \mathrm{~d}^{-1}$ on $9 / 21$ to $285 \pm 14 \mathrm{mg}-\mathrm{C} \mathrm{m}^{-2} \mathrm{~d}^{-1}$ on $10 / 3$, and then reached a maximum value of $552 \pm 28 \mathrm{mg}_{-} \mathrm{C} \mathrm{m}^{-2} \mathrm{~d}^{-1}$ on $10 / 6$ (Fig. 3). We did not have transmissometer data (TM \%) in this study, but the elevated post-typhoon POC export flux is unlikely to have been caused by lateral transport of coastal waters or riverine input. The TM values increased with increasing depth (Fig. 4, data extracted from Hung et al. $2010 \mathrm{~b}, 2012)$ demonstrating not only a low concentration of particles in deeper waters, but also an absence of laterally injected nepheloid layers. In other words, in situ surface chl $a$ and POC flux data provide evidence that typhoons indeed increase phytoplankton biomass and biogenic carbon flux after their passages.

\section{DISCUSSION}

\subsection{Cooling Forcing and Hydrographic Variations Dur- ing Pre- and Post-typhoon Periods}

The cooling of the SST caused by Typhoon Jangmi could be caused by several different processes including wind enhanced vertical mixing, wind induced upwelling (Price 1981), evaporative heat loss and a reduction in solar insolation (due to increased cloud cover). In addition to physical factors, changes in the movement of the main stream of the Kuroshio Current may also affect the coastal upwelling strength (Tsai et al. 2008; Wu et al. 2008b). Furthermore, the transit speed of a typhoon (Babin et al. 2004; Walker et al. 2006; Zhao et al. 2008) and the bottom depth (Siswanto et al. 2007) may influence hydrographic variations in the water column after typhoon events. For example, when a typhoon propagates from deep water to a shallow

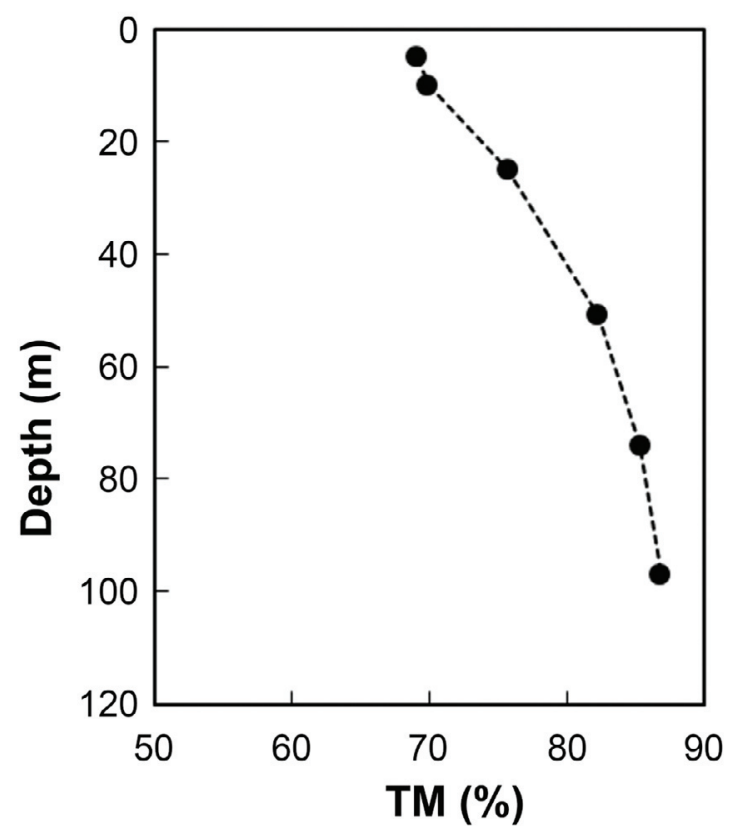

Fig. 4. Vertical profile of transmissometer [\% transmission, TM (\%)] data in the SECS five days after the passage of Typhoon Fungwong (data from Hung et al. 2012). 
area, bottom depth-inertially forced currents will enhance turbulent mixing and upwelling, resulting in more nutrientwater entrainment in the shelf than in the off-shelf waters (Siswanto et al. 2007). This cooling phenomenon caused by upwelled Kuroshio subsurface water in the SECS after the passage of a typhoon has frequently been observed before (Siswanto et al. 2007; Chang et al. 2008; Tsai et al. 2008; Zhao et al. 2008; Hung et al. 2010a; Hung and Gong 2011). The mechanisms of typhoon-induced SST cooling have also previously been studied by Tsai et al. (2008) and Morimoto et al. (2009). These authors reported that the typhoon triggers the intrusion of the subsurface Kuroshio water onto the shelf through complicated interactions of wind, current, and topography, causing the decreases in SST off the northeastern coast of Taiwan. Detailed processes involved in the Morakot-induced Kuroshio water intrusion and the associated decrease in SST can be found in Tsai et al. (2013).

Here we used the one-dimensional turbulence model developed by Mellor and Yamada (1982) to simulate the effects of the passage of a typhoon on the variation in mixed layer depths and temperatures. The simulating result is the development of the mixed layer induced by a typhoon with various wind speeds ranging from 20 to $50 \mathrm{~m} \mathrm{~s}^{-1}$, respectively. The initial temperature profile was taken from the measured data similar to the study area on 26 August 2009 under non-typhoon conditions. The wind speed is given as $40 \mathrm{~m} \mathrm{~s}^{-1}$, the simulation time is 36 hours, and the data output interval is 2 hours. The simulated temperature profiles show that the surface mixed layer deepened from $<20 \mathrm{~m}$ to deeper than $70 \mathrm{~m}$ within 36 hours. The simulated SST will decrease from 27.8 to $25.7^{\circ} \mathrm{C}$ on $9 / 29$ if the simulation model is starting at $6 \mathrm{pm}$ on $9 / 27$. The CPSST on $9 / 29$ was $24.3^{\circ} \mathrm{C}$ similar to the simulated value, if standard deviations $\left(0.5 \sim 1.0^{\circ} \mathrm{C}\right)$ of satellite derived SST and daily variation of in situ SST $\left(0.5\right.$ to $1.2^{\circ} \mathrm{C}$, Gong et al. 1995) are considered. Thus, the reduction in temperature in the SECS is produced primarily by vertical mixing shortly after the passage of the strong Typhoon Jangmi. As mentioned earlier, Jangmi traveled slowly during 9/28 $29\left(3.3 \sim 3.8 \mathrm{~m} \mathrm{~s}^{-1}\right)$, which might cause strong upwelling that coincided with in situ SST $\left(24.0 \pm 0.3^{\circ} \mathrm{C}\right)$ on $10 / 6$ after several days. Furthermore, according to the hurricane's propagation speed, the maximum SST drop is $5.3^{\circ} \mathrm{C}$ for a slow hurricane $\left(<4 \mathrm{~m} \mathrm{~s}^{-1}\right)$ and $3.5^{\circ} \mathrm{C}$ for a medium hurricane $\left(4 \sim 8 \mathrm{~m} \mathrm{~s}^{-1}\right)$ (Bender et al. 1993). Therefore, we cannot exclude the effect of upwelling in reduction in surface temperature in the SECS.

Before typhoon conditions, surface nitrate concentrations in the SECS were low (e.g., $\sim 0.3 \mu \mathrm{M}$ on 9/17 21). After the passage of Typhoon Jangmi, nutrient-rich subsurface water were brought and/or entrained to the surface waters, with nitrate concentrations ranging from 1.9 to $2.3 \mu \mathrm{M}$ (Table 1). The simulated surface nitrate concentration, based on the model crafted by Mellor and Yamada (1982), would gradually increase from $0 \mu \mathrm{M}$ on $9 / 27$ to approxi- mately $2 \mu \mathrm{M}$ on $9 / 29$ if the wind speed is given as $40 \mathrm{~m} \mathrm{~s}^{-1}$ and conditions are the same as in the temperature simulation (Fig. 5). This suggests that the simulated nitrate concentration is very similar to in situ nitrate concentrations. The sea-based nitrate concentrations $(2.3 \pm 1.1 \mu \mathrm{M}$ on $10 / 3$ and $1.9 \pm 0.5 \mu \mathrm{M}$ on $10 / 6$ ) were similar to the predicted surface nitrate concentrations $(2 \mu \mathrm{M})$, as estimated by the turbulence model if the spatial variation of nitrate concentrations is considered. Consequently, it is expected that nitrate concentrations in surface water should quickly decrease several days after the nutrient-rich water was pumped into the surface layer. However, in situ measured nitrate concentrations were not rapidly consumed by phytoplankton (Table 1). This implies that phytoplankton biomass stock may have been constrained by several factors such as water converging at depth and diverging at the surface (Tsai et al. 2013), light limitation and intense grazing pressure by zooplankton (Hung et al. 2010a; Chung et al. 2012).

Additionally, the upwelled nitrate will be diluted by the surrounding water and transported to the northern ECS or the adjacent regions along the Kuroshio supporting phytoplankton growth. The cold water patches are difficult to track and surface cooling may have quickly disappeared because waters are easily mixed with ambient warm water in the summer.

\subsection{Implications for POC Fluxes After Typhoon Events}

Biogenic carbon flux from the euphotic zone of the ocean to the deep ocean is one of the main factors which influences the $\mathrm{CO}_{2}$ partial pressure in the atmosphere. Therefore, the measurement of this POC flux is very important to understand the global carbon cycle and its response to climate change (Emerson et al. 1997). Typhoons have a notable impact on POC flux, but one may ask the question how important are they around the world compared to other upwelling systems which are determined by either the sediment trap method or carbon budget (González et al. 2000, 2007; Olli et al. 2001; Arístegui et al. 2004; Monteiro et al. 2006; Montero et al. 2007; Thunell et al. 2007; Chou et al. 2009; Montes et al. 2012) or ${ }^{234} \mathrm{Th} /{ }^{238} \mathrm{U}$ disequilibrium approach (Murray et al. 1989; Bacon et al. 1996; Moran et al. 2005; Wei et al. 2009, 2010). We found that POC fluxes in this study after a typhoon are only less than POC fluxes reported in the Chukchi Sea (Arctic, POC flux $=0.4 \sim 468 \mathrm{mg}_{-} \mathrm{C} \mathrm{m}^{-2} \mathrm{~d}^{-1}$ ) and Cariaco Basin (Venezuela, POC flux $=390-950 \mathrm{mg}^{-} \mathrm{C} \mathrm{m}^{-2} \mathrm{~d}^{-1}$ ) and much higher than other POC fluxes in other locations (Fig. 6). The results suggest that a nutrient supply after typhoon events indeed can stimulate a phytoplankton bloom (from small phytoplankton to large chain-forming centric diatoms, causing intensive grazing by zooplankton (Chung et al. 2012) and then result in enhanced POC export flux.

Furthermore, we can use an e-ratio ( $=$ POC flux/I-PP) to estimate the carbon transport efficiency in the water column. 
(a)

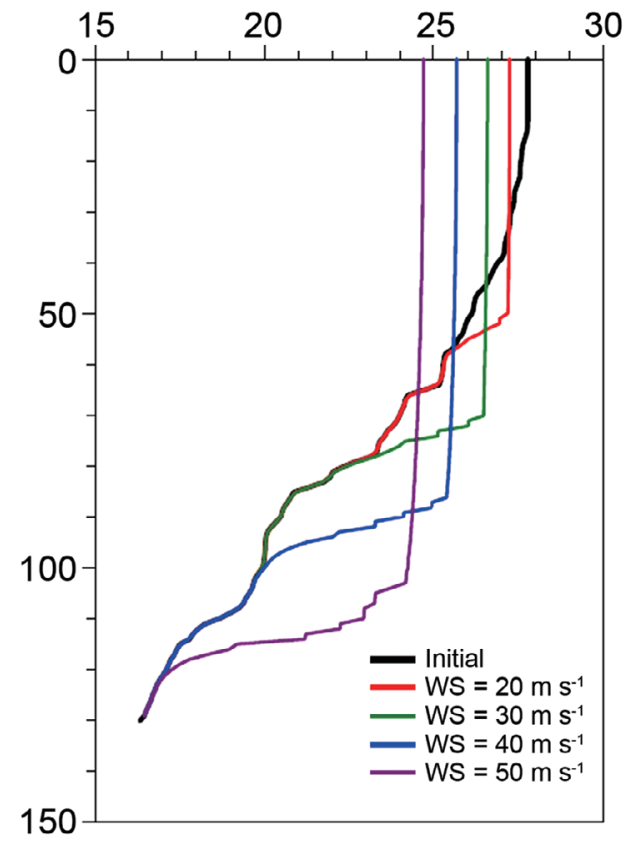

(b)

\section{Nitrate $(\mu \mathrm{m})$}

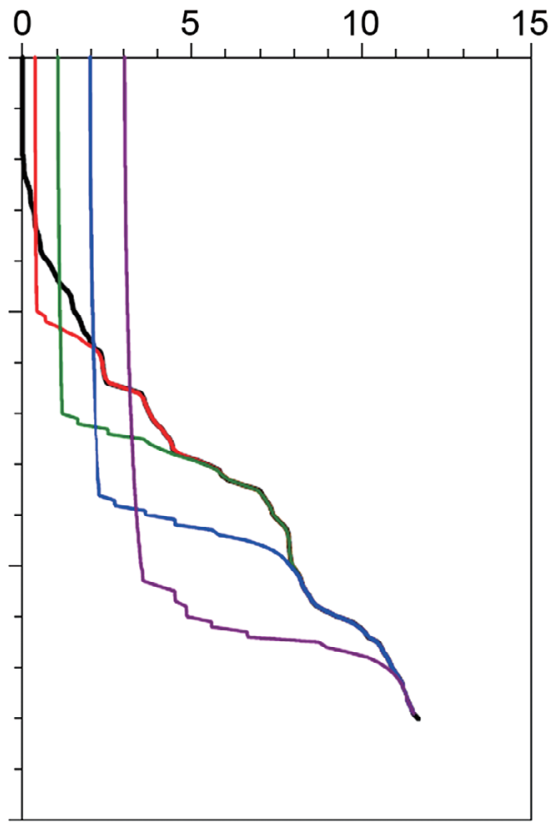

Fig. 5. (a) The simulated result of the development of the surface mixed layer and (b) nitrate concentration induced by a typhoon. In this simulation, the initial temperature (nitrate) profile (black solid line) was taken from the measured data in the SECS in summer, the wind speed was taken as increasing from 20 to $50 \mathrm{~m} \mathrm{~s}^{-1}$, the simulation time was 36 hours, and the data output interval was 2 hours. The simulated temperature profiles show that the surface mixed layer deepened from 10 to deeper than $80 \mathrm{~m}$ within 36 hours (blue solid line). The simulated surface nitrate concentrations were between 1 and $2 \mu \mathrm{M}$, which are in agreement with the observed values.

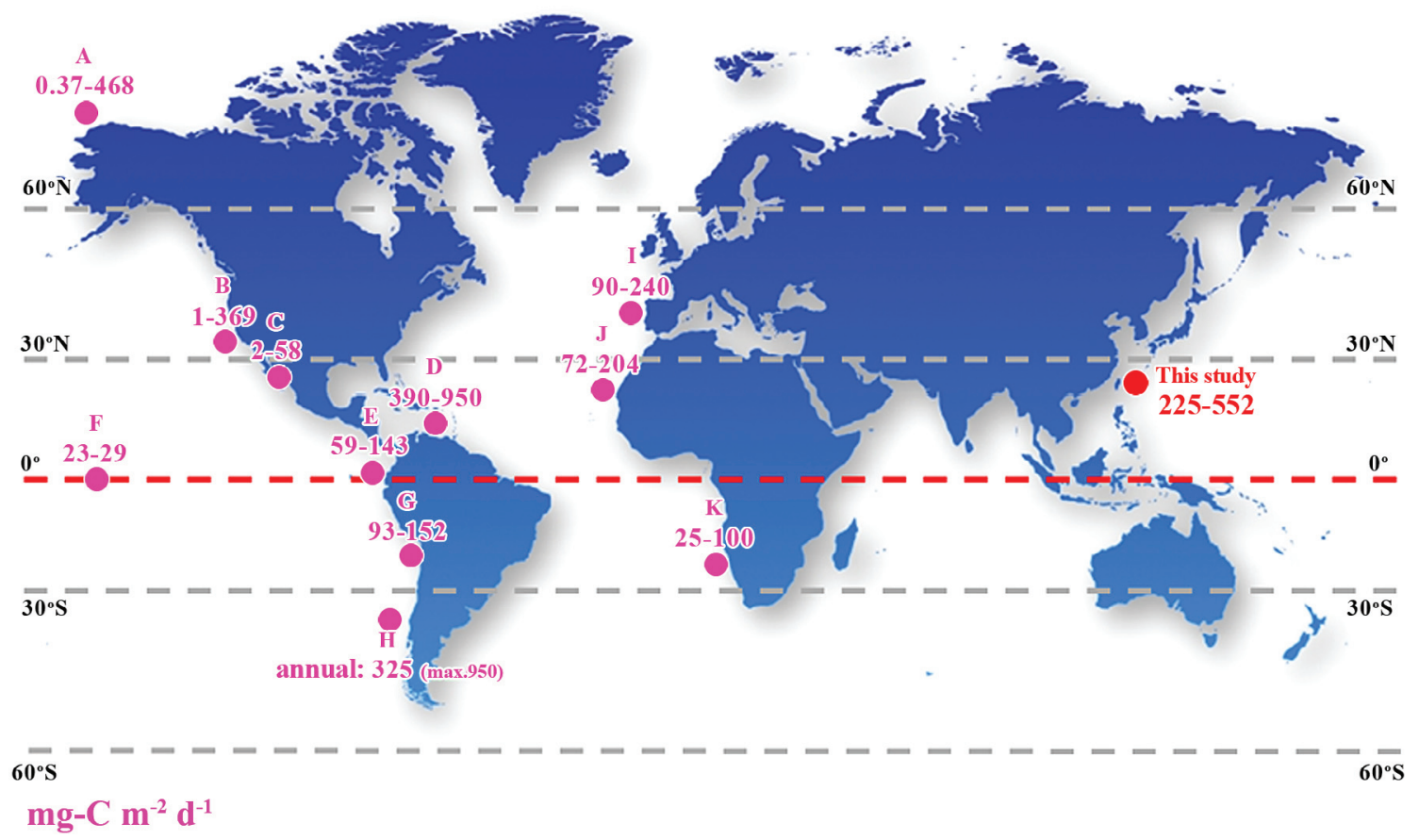

Fig. 6. Comparisons of POC fluxes between the study area, pre- and post-effects of a typhoon in the SECS, and upwelling zones around the world. A: Moran et al. 2005. B: Thunell et al. 2007. C: Thunell et al. 2007. D: Montes et al. 2012. E: Murray et al. 1989. F: Bacon et al. 1996. G: González et al. 2000. H: González et al. 2007. I: Olli et al. 2001. J: Arístegui et al. 2004. K: Monteiro et al. 2006. 
Table 1 shows variations of e-ratios before $(e=0.13 \sim 0.16)$ and after $(\mathrm{e}=0.21 \sim 0.28)$ the passage of Typhoon Jangmi. In comparison, Hung et al. (2010a) reported that e-ratios ranged from $0.11 \sim 0.16$ during a period under non-typhoon conditions. Although both the POC flux measurements and I-PP estimations have analytical errors (Table 1), the observed results provided direct evidence that biogenic particles can efficiently transport POC below the euphotic zone after the passage of a typhoon.

The enhanced POC flux after passage of the typhoon might be caused by the evolution of a phytoplankton community. We did not investigate phytoplankton species composition in the present study, however, Chang et al. (1996) and Chung et al. (2012) reported that major phytoplankton assemblages in the ECS before a typhoon were composed of small phytoplankton, including dinoflagellates, gymnodinium spp. and trichdesmium spp., and then changed to large chain-forming centric diatoms (Chaetoceros spp.) after the typhoon's passage (Chung et al. 2012). Analogous phytoplankton species changes have been reported in the Kuroshio Current (Chen et al. 2009). In addition to phytoplankton assemblage changes, other factors, zooplankton grazing (e.g., enhancing fecal pellets production) (Chung et al. 2012), aggregation of small particles, and mineral ballast effects, may also be involved in enhancing the biogenic POC flux. Further studies are required to conduct vertical profiles of water properties and POC fluxes before and after the passage of a typhoon and to quantify the effect of storm events to global POC export flux in other marine environments, including marginal seas and tropical open oceans.

As mentioned before, Hung et al. (2010a) showed that POC fluxes determined using un-poisoned traps are similar to those in $\mathrm{HgCl}$ poisoned during short-term trap deployments. In addition, Hung et al. (2010b) also reported that there is no significant difference in POC flux between night $\left(53.3 \pm 8.5 \mathrm{mg}^{-C} \mathrm{~m}^{-2} \mathrm{~d}^{-1}\right)$ and day $\left(45.9 \pm 6.9 \mathrm{mg}^{-C} \mathrm{~m}^{-2} \mathrm{~d}^{-1}\right)$ in the ECS. This agrees with observations by $\mathrm{Li}$ (2009) who investigated POC fluxes using a time-series (4, 8, 12 and 24 hours) of trap deployments in the same region of the present study and also found no significant difference in POC flux between night and day. Thus, if diurnal variability in POC flux occurs, this may be small compared to other possible sources of error in our measurements. The trapping efficiency of floating sediment traps was $75 \%$ in the outer shelf of the East China Sea (Li 2009) and 80\% in the oligotrophic water of the northwest Pacific Ocean (Hung and Gong 2007), based on the ${ }^{234} \mathrm{Th} /{ }^{238} \mathrm{U}$ disequilibrium model used by Hung et al. (2010a).

\section{CONCLUSIONS}

Based upon sea-based observations of POC fluxes before and shortly after the passage of Typhoon Jangmi in the SECS, we conclude: (1) strong typhoons indeed have an important impact on SST, nitrate, chl a concentrations and POC flux based on in situ observations in the SECS, and, (2) both in situ chl $a$ concentrations and POC fluxes after a typhoon were much greater than those before the passage. The enhanced POC export flux was attributed to a phytoplankton bloom, which was evidenced by in situ elevated chl $a$ concentrations

Acknowledgements We appreciate the assistance of $\mathrm{W}$. J. Chung and S. L. Li. This research was supported by the Top University Program and the National Science Council (NSC101-2116-M-110-001, NSC101-2611-M-110-015MY3, NSC100-2119-M-110-003) of Taiwan.

\section{REFERENCES}

Arístegui, J., E. D. Barton, P. Tett, M. F. Montero, M. García-Muñoz, G. Basterretxea, A.-S. Cussatlegras, A. Ojeda, and D. de Armas, 2004: Variability in plankton community structure, metabolism, and vertical carbon fluxes along an upwelling filament (Cape Juby, NW Africa). Prog. Oceanogr., 62, 95-113, doi: 10.1016/j. pocean.2004.07.004. [Link]

Babin, S. M., J. A. Carton, T. D. Dickey, and J. D. Wiggert, 2004: Satellite evidence of hurricane-induced phytoplankton blooms in an oceanic desert. J. Geophys. Res., 109, C03043, doi: 10.1029/2003JC001938. [Link]

Bacon, M. P., J. K. Cochran, D. Hirschberg, T. R. Hammar, and A. P. Fleer, 1996: Export flux of carbon at the equator during the EqPac time-series cruises estimated from ${ }^{234}$ Th measurements. Deep-Sea Res. Part II-Top. Stud. Oceanogr., 43, 1133-1153, doi: 10.1016/09670645(96)00016-1. [Link]

Behrenfeld, M. J. and P. G. Falkowski, 1997: Photosynthetic rates derived from satellite-based chlorophyll concentration. Limnol. Oceanogr., 42, 1-20, doi: 10.4319/ 10.1997.42.1.0001. [Link]

Bender, M. A., I. Ginis, and I. Kurihara, 1993: Numerical simulations of tropical cyclone-ocean interaction with a high-resolution coupled model. J. Geophys. Res., 98, 23245-23263, doi: 10.1029/93JD02370. [Link]

Chang, J., C. C. Chung, and G. C. Gong, 1996: Influences of cyclones on chlorophyll $a$ concentration and Synechococcus abundance in a subtropical western Pacific coastal ecosystem. Mar. Ecol. Prog. Ser., 140, 199205, doi: 10.3354/meps140199. [Link]

Chang, Y., H. T. Liao, M. A. Lee, J. W. Chan, W. J.Shieh, K. T. Lee, G. H. Wang, and Y. C. Lan, 2008: Multisatellite observation on upwelling after the passage of Typhoon Hai-Tang in the southern East China Sea. Geophys. Res. Lett., 35, L03612, doi: 10.1029/2007GL032858. [Link]

Chen, Y. and D. Tang, 2012: Eddy-feature phytoplankton bloom induced by a tropical cyclone in the South 
China Sea. Int. J. Remote Sens., 33, 7444-7457, doi: 10.1080/01431161.2012.685976. [Link]

Chen, Y. L. L., H. Y. Chen, S. Jan, and S. H. Tuo, 2009: Phytoplankton productivity enhancement and assemblage change in the upstream Kuroshio after typhoons. Mar. Ecol.Prog. Ser., 385, 111-126, doi: 10.3354/meps 08053. [Link]

Chern, C. S., J. Wang, and D. P. Wang, 1990: The exchange of Kuroshio and East China Sea shelf water. J. Geophys. Res., 95, 16017-16023, doi: 10.1029/JC095iC09 p16017. [Link]

Chou, W. C., G. C. Gong, D. D. Sheu, S. Jen, C. C. Hung, and C. C. Chen, 2009: Reconciling the paradox that the heterotrophic waters of the East China Sea shelf act as a significant $\mathrm{CO}_{2}$ sink during the summertime: Evidence and implications. Geophys. Res. Lett., 36, L15607, doi: 10.1029/2009GL038475. [Link]

Chou, W. C., G. C. Gong, W. J. Cai, D. D. Sheu, C. C. Hung, H. Y. Chen, and C. C. Chung, 2011: $\mathrm{CO}_{2}$ system in the oligotrophic northwest Pacific Ocean during the Asian dust storm season. Mar. Chem., 127, 210-222, doi: 10.1016/j.marchem.2011.09.005. [Link]

Chung, C. C., G. C. Gong, and C. C. Hung, 2012: Effect of Typhoon Morakot on microphytoplankton population dynamics in the subtropical Northwest Pacific. Mar. Ecol. Prog. Ser., 448, 39-49, doi: 10.3354/meps09490. [Link]

Emerson, S., P. Quay, D. Karl, C. Winn, L. Tupas, and M. Landry, 1997: Experimental determination of the organic carbon flux from open-ocean surface waters. $\mathrm{Na}$ ture, 389, 951 - 954, doi: 10.1038/40111. [Link]

Fritz, H. M., C. Blount, R. Sokoloski, J. Singleton, A. Fuggle, B. G. McAdoo, A. Moore, C. Grass, and B. Tate, 2007: Hurricane Katrina storm surge distribution and field observations on the Mississippi Barrier Islands. Estuar. Coast. Shelf Sci., 74, 12-20, doi: 10.1016/j. ecss.2007.03.015. [Link]

Gong, G. C., K. K. Liu, C. T. Liu, and S. C. Pai, 1992: The chemical hydrography of the South China Sea west of Luzon and a comparison with the west Philippine Sea. Terr. Atmos. Ocean. Sci., 3, 587-602.

Gong, G. C., K. K. Liu, and S. C. Pai, 1995: Prediction of nitrate concentration from two end member mixing in the southern East China Sea. Cont. Shelf Res., 15, 827842, doi: 10.1016/0278-4343(94)00039-p. [Link]

Gong, G. C., F. K. Shiah, K. K. Liu, Y. H. Wen, and M. H. Liang, 2000: Spatial and temporal variation of chlorophyll $a$, primary productivity and chemical hydrography in the southern East China Sea. Cont. Shelf Res., 20, 411-436, doi: 10.1016/s0278-4343(99)000 79-5. [Link $]$

Gong, G. C., J. Chang, and M. H. Liang, 2001: A photosynthetic-irradiance model for the upwelling region northeast of Taiwan and its application to the East
China Sea. J. Geophys. Res., 106, 19957-19968, doi: 10.1029/1999JC000044. [Link]

González, H. E., V. C. Ortiz, and M. Sobarzo, 2000: The role of faecal material in the particulate organic carbon flux in the northern Humboldt Current, Chile $\left(23^{\circ} \mathrm{S}\right)$, before and during the 1997 - 1998 El Niño. J. Plankton Res., 22, 499-529, doi: 10.1093/plankt/22.3.499. [Link]

González, H. E., E. Menschel, C. Aparicio, and C. Barría, 2007: Spatial and temporal variability of microplankton and detritus, and their export to the shelf sediments in the upwelling area off Concepción, Chile $\left(\sim 36^{\circ} \mathrm{S}\right)$, during 2002 - 2005. Prog. Oceanogr., 75, 435-451, doi: 10.1016/j.pocean.2007.08.025. [Link]

Huang, C. Y., C. S. Wong, and T. C. Yeh, 2011: Extreme rainfall mechanisms exhibited by Typhoon Morakot (2009). Terr. Atmos. Ocean. Sci., 22, 613-632, doi: 10. 3319/TAO.2011.07.01.01(TM). [Link]

Hung, C. C. and G. C. Gong, 2007: Export flux of POC in the main stream of the Kuroshio. Geophys. Res. Lett., 34, L18606, doi: 10.1029/2007GL030236. [Link]

Hung, C. C. and G. C. Gong, 2011: Biogeochemical responses in the southern East China Sea after typhoons. Oceanography, 24, 42-51, doi: 10.5670/oceanog.2011. 93. [Link]

Hung, C. C., G. T. F. Wong, K. K. Liu, F. K. Shiah, and G. C. Gong, 2000: The effects of light and nitrate levels on the relationship between nitrate reductase activity and ${ }^{15} \mathrm{NO}_{3}^{-}$uptake: Field observations in the East China Sea. Limnol. Oceanogr., 45, 836-848, doi: 10.4319/ lo.2000.45.4.0836. [Link]

Hung, C. C., L. Guo, G. E. Schultz Jr., J. L. Pinckney, and P. H. Santschi, 2003: Production and flux of carbohydrate species in the Gulf of Mexico. Global Biogeochem. Cycles, 17, 1055, doi: 10.1029/2002GB001988. [Link]

Hung, C. C., L. Guo, K. A. Roberts, and P. H. Santschi, 2004: Upper ocean carbon flux determined by the ${ }^{234} \mathrm{Th}$ approach and sediment traps using size-fractionated POC and ${ }^{234} \mathrm{Th}$ data from the Gulf of Mexico. Geochem. J., 38, 601-611, doi: 10.2343/geochemj.38.601. [Link]

Hung, C. C., K. W. Warnken, and P. H. Santschi, 2005: A seasonal survey of carbohydrates and uronic acids in the Trinity River, Texas. Org. Geochem., 36, 463-474, doi: 10.1016/j.orggeochem.2004.09.004. [Link]

Hung, C. C., G. C. Gong, H. Y. Chen, H. L. Hsieh, P. H. Santschi, T. L. Wade, and J. L. Sericano, 2007: Relationships between pesticides and organic carbon fractions in sediments of the Danshui River estuary and adjacent coastal areas of Taiwan. Environ. Pollut., 148, 546-554, doi: 10.1016/j.envpol.2006.11.036. [Link]

Hung, C. C., G. C. Gong, W. C. Chung, W. T. Kuo, and F. C. Lin, 2009: Enhancement of particulate organic 
carbon export flux induced by atmospheric forcing in the subtropical oligotrophic northwest Pacific Ocean. Mar.Chem., 113, 19-24, doi: 10.1016/j.marchem.2008. 11.004. [Link]

Hung, C. C., G. C. Gong, W. C. Chou, C. C. Chung, M. A. Lee, Y. Chang, H. Y. Chen, S. J. Huang, Y. Yang, W. R. Yang, W. C. Chung, S. L. Li, and E. Laws, 2010a: The effect of typhoon on particulate organic carbon flux in the southern East China Sea. Biogeosciences, 7, 3007-3018, doi: 10.5194/bg-7-3007-2010. [Link]

Hung, C. C., C. Xu, P. H. Santschi, S. J. Zhang, K. A. Schwehr, A. Quigg, L. Guo, G. C. Gong, J. L. Pinckney, R. A. Long, and C. L. Wei, 2010b: Comparative evaluation of sediment trap and ${ }^{234} \mathrm{Th}$-derived POC fluxes from the upper oligotrophic waters of the Gulf of Mexico and the subtropical northwestern Pacific Ocean. Mar. Chem., 121, 132-144, doi: 10.1016/j.marchem. 2010.03.011. [Link]

Hung, C. C., G. C. Gong, and P. H. Santschi, 2012: ${ }^{234}$ Th in different size classes of sediment trap collected particles from the Northwestern Pacific Ocean. Geochim. Cosmochim. Acta, 91, 60-74, doi: 10.1016/j.gca.2012. 05.017. [Link]

Hung, C. C., C. C. Chung, G. C. Gong, S. Jan, Y. Tsai, K. S. Chen, W. C. Chou, M. A. Lee, Y. Chang, M. H. Chen, W. R. Yang, C. J. Tseng, and G. Gawarkiewicz, 2013: Nutrient supply in the southern East China Sea after typhoon Morakot. J. Mar. Res., 71, 133-150.

Jan, S., C. C. Chen, Y. L. Tsai, Y. J. Yang, J. Wang, C. S. Chern, G. Gawarkiewicz, R. C. Lien, L. Centurioni, and J. Y. Kuo, 2011: Mean structure and variability of the cold dome northeast of Taiwan. Oceanography, 24, 100-109, doi: 10.5670/oceanog.2011.98. [Link]

Jan, S., J. Wang, Y. J. Yang, C. C. Hung, C. S. Chern, G. Gawaqrkiewicz, R. C. Lien, L. Centurioni, J. Y. Kuo, and B. Wang, 2013: Observations of a freshwater pulse induced by Typhoon Morakot off the northern coast of Taiwan in August 2009. J. Mar. Res., 71, 19-46.

Li, S. L., 2009: Particulate organic carbon flux in the upwelling region off northeastern Taiwan. Master Thesis, National Taiwan Ocean University, Keelung, Taiwan, $150 \mathrm{pp}$.

Liu, K. K., G. C. Gong, S. Lin, C. Y. Yang, C. L. Wei, S. C. Pai, and C. K. Wu, 1992: The year-round upwelling at the shelf break near the northern tip of Taiwan as evidenced by chemical hydrography. Terr. Atmos. Ocean. Sci., 3, 243-276.

Liu, K. K., Z. L. Lai, G. C. Gong, and F. K. Shiah, 1995: Distribution of particulate organic matter in the southern East China Sea: Implications in production and transport. Terr. Atmos. Ocean. Sci., 6, 27-45.

Mellor, G. L. and T. Yamada, 1982: Development of a turbulence closure model for geophysical fluid problems. Rev. Geophys., 20, 851-875, doi: 10.1029/RG02 0i004p00851. [Link]

Monteiro, P. M. S., A. van der Plas, V. Mohrholz, E. Mabille, A. Pascall, and W. Joubert, 2006: Variability of natural hypoxia and methane in a coastal upwelling system: Oceanic physics or shelf biology? Geophys. Res. Lett., 33, L16614, doi: 10.1029/2006GL026234. [Link]

Montero, P., G. Daneri, L. A. Cuevas, H. E. González, B. Jacob, L. Lizárraga, and E. Menschel, 2007: Productivity cycles in the coastal upwelling area off Concepción: The importance of diatoms and bacterioplankton in the organic carbon flux. Prog. Oceanogr., 75, 518-530, doi: 10.1016/j.pocean.2007.08.013. [Link]

Montes, E., F. Muller-Karger, R. Thunell, D. Hollander, Y. Astor, R. Varela, I. Soto, and L. Lorenzoni, 2012: Vertical fluxes of particulate biogenic material through the euphotic and twilight zones in the Cariaco Basin, Venezuela. Deep-Sea Res. Part I-Oceanogr. Res. Pap., 67, 73-84, doi: 10.1016/j.dsr.2012.05.005. [Link]

Moran, S. B., R. P. Kelly, K. Hagstrom, J. N. Smith, J. M. Grebmeier, L. W. Cooper, G. F. Cota, J. J. Walsh, N. R. Bates, D. A. Hansell, W. Maslowski, R. P. Nelson, and S. Mulsow, 2005: Seasonal changes in POC export flux in the Chukchi Sea and implications for water column-benthic coupling in Arctic shelves. Deep-Sea Res. Part II-Top. Stud. Oceanogr., 52, 3427-3451, doi: 10.1016/j.dsr2.2005.09.011. [Link]

Morimoto, A., S. Kojima, S. Jan, and D. Takahashi, 2009: Movement of the Kuroshio axis to the northeast shelf of Taiwan during typhoon events. Estuar. Coast. Shelf Sci., 82, 547-552, doi: 10.1016/j.ecss.2009.02.022. [Link]

Murray, J. W., J. N. Downs, S. Strom, C. L. Wei, and H. W. Jannasch, 1989: Nutrient assimilation, export production and ${ }^{234} \mathrm{Th}$ scavenging in the eastern equatorial Pacific. Deep-Sea Res. Part I-Oceanogr. Res. Pap., 36, 1471-1489, doi: 10.1016/0198-0149(89)90052-6. [Link]

Olli, K., C. W. Riser, P. Wassmann, T. Ratkova, E. Arashkevich, and A. Pasternak, 2001: Vertical flux of biogenic matter during a Lagrangian study off the NW Spanish continental margin. Prog. Oceanogr., 51, 443466, doi: 10.1016/S0079-6611(01)00079-9. [Link]

Price, J. F., 1981: Upper ocean response to a hurricane. J. Phys. Oceanogr., 11, 153- 175, doi: 10.1175/1520-048 5(1981)011<0153:UORTAH>2.0.CO;2. [Link]

Rao, A. D., M. Joshi, I. Jain, and M. Ravichandran, 2010: Response of subsurface waters in the eastern Arabian Sea to tropical cyclones. Estuar. Coast. Shelf Sci., 89, 267-276, doi: 10.1016/j.ecss.2010.07.011. [Link]

Shang, S., L. Li, F. Sun, J. Wu, C. Hu, D. Chen, X. Ning, Y. Qiu, C. Zhang, and S. Shang, 2008: Changes of temperature and bio-optical properties in the South China Sea in response to Typhoon Lingling, 2001. Geophys. 
Res. Lett., 35, L10602, doi: 10.1029/2008GL033502. [Link]

Shiah, F. K., S. W. Chung, S. J. Kao, G. C. Gong, and K. K. Liu, 2000: Biological and hydrographical responses to tropical cyclones (typhoons) in the continental shelf of the Taiwan Strait. Cont. Shelf Res., 20, 2029-2044, doi: 10.1016/s0278-4343(00)00055-8. [Link]

Siswanto, E., J. Ishizaka, K. Yokouchi, K. Tanaka, and C. K. Tan, 2007: Estimation of interannual and interdecadal variations of typhoon-induced primary production: A case study for the outer shelf of the East China Sea. Geophys. Res. Lett., 34, L03604, doi: 10.1029/2006 GL028368. [Link]

Thunell, R., C. Benitez-Nelson, R. Varela, Y. Astor, and F. Muller-Karger, 2007: Particulate organic carbon fluxes along upwelling-dominated continental margins: Rates and mechanisms. Global Biogeochem. Cycles, 21, GB 1022, doi: 10.1029/2006GB002793. [Link]

Tsai, Y., C. S. Chern, and J. Wang, 2008: Typhoon induced upper ocean cooling off northeastern Taiwan. Geophys. Res. Lett., 35, L14605, doi: 10.1029/2008GL034368. [Link]

Tsai, Y., C. S. Chern, S. Jan, and J. Wang, 2013: Numerical study of cold dome variability induced by Typhoon Morakot (2009) off northeastern Taiwan. J. Mar. Res., 71, 109-132.

Walker, N. D., A. Haag, S. Balasubramanian, R. Leben, I. van Heerden, P. Kemp, and H. Mashriqui, 2006: Hurricane prediction: A century of advances. Oceanogra- phy, 19, 24-36, doi: 10.5670/oceanog.2006.60. [Link]

Wei, C. L., L. H. Chou, J. R. Tsai, L. S. Wen, and S. C. Pai, 2009: Comparative geochemistry of ${ }^{234} \mathrm{Th},{ }^{210} \mathrm{~Pb}$, and ${ }^{210} \mathrm{Po}$ : A case study in the Hung-Tsai Trough off southwestern Taiwan. Terr. Atmos. Ocean. Sci., 20, 411423, doi: 10.3319/TAO.2008.01.09.01(Oc) [Link]

Wei, C. L., J. R. Tsai, Y. R. Hou, L. S. Wen, D. D. Sheu, and W. C. Chou, 2010: Scavenging phenomenon elucidated from ${ }^{234} \mathrm{Th} /{ }^{238} \mathrm{U}$ disequilibrium in surface water of the Taiwan Strait. Terr. Atmos. Ocean. Sci., 21, 713726, doi: 10.3319/TAO.2009.08.26.01(Oc). [Link]

Wu, C. R., Y. L. Chang, L. Y. Oey, C.-W. J. Chang, and Y.C. Hsin, 2008a: Air-sea interaction between tropical cyclone Nari and Kuroshio. Geophys. Res. Lett., 35, L12605, doi: 10.1029/2008GL033942. [Link]

Wu, C. R., H. F. Lu, and S. Y. Chao, 2008b: A numerical study on the formation of upwelling off northeast Taiwan. J. Geophys. Res., 113, C08025, doi: 10.1029/ 2007JC004697. [Link]

Zhao, H., D. L. Tang, and Y. Wang, 2008: Comparison of phytoplankton blooms triggered by two typhoons with different intensities and translation speeds in the South China Sea. Mar. Ecol. Prog. Ser., 365, 57-65, doi: 10. 3354/meps07488. [Link]

Zheng, G. M. and D. L. Tang, 2007: Offshore and nearshore chlorophyll increases induced by typhoon winds and subsequent terrestrial rainwater runoff. Mar. Ecol. Prog. Ser., 333, 61-74, doi: 10.3354/meps333061. [Link] 